\title{
IMPROVING STUDENTS' LISTENING SKILL THROUGH SHADOWING
}

\author{
Mukminatus Zuhriyah \\ Universitas Hasyim Asy'ari Tebuireng Jombang \\ zoehrea@gmail.com
}

\begin{abstract}
Listening is the first part of language skills that everyone gets when learning a language. It comes before speaking, reading, and writing. Meanwhile, most of the students get difficulty to learn listening of a foreign language, especially English. That is why shadowing was applied in the listening class as one of the solutions to make the learners of English listening easy to understand what the speaker says. This collaborative classroom action research was generally to know whether or not shadowing could improve the students listening skill. It was also specifically to know: (1) the lecturer's activities, (2) the students' activities, and (3) the students' responses during the implementation of shadowing in the listening class. The subjects were 18 students of the third semester of English department of education faculty of Hasyim Asy'ari university (UNHASY) Tebuireng Jombang in the academic year of 2016/2017. The data were obtained from the observations got from the notes written by the collaborator and the listening test. The students' listening skill improved after the implementation of shadowing. It could be seen in the improvement of mean score, from 74.2 in cycle one to 75 in cycle two. Then, the precentage of students passing the minimum mastery criteria also improved, from $61 \%$ in cycle one to $77.8 \%$ in cycle two. Thus, it can be concluded that shadowing could improve students' listening skill.
\end{abstract}

Keywords: Listening Skill, Shadowing, UNHASY Students

\section{INTRODUCTION}

All the students learning English are hoped to be able to master the four English skills. Among those skills, listening becomes the most important part of English skills. Listening is the first stage in learning English. It is because listening comes at first before somebody speaks, reads, or writes. Listening becomes a bridge when learning to speak, to read, and to write. In line with this, Sevik (2012: 328) states that a person who learns a second or foreign language (FL) will first hear, then, talk, and followed by learning how to read and write. Then, Adelmann (2012: 514) states that a language learner needs competent listening skill when learning a language. Additionally, Ghanbari and Hashemian (2014: 337) state that good listening comprehension has the basic part for developing other skills in foreign language learning. 
English department of education faculty of Hasyim Asy'ari University, Tebuireng Jombang, puts the listening in the first up to the fourth semester. The main objective of the listening course itself is to make the students able to understand what the native speakers say about correctly. Dealing with this situation, Schmidt (2016:2) found that listening is the most difficult skill to contend as a language learner. Then, based on the data on the preliminary study held on September 6, 2016, most of the students of UNHASY still got low score, under 75. Their mean score was 70.8 . The percentage of the students getting 75 was $39 \%$. It means that they still have low listening skill. Meanwhile, Arono (2014: 63) says that the teacher is still lack of commitment in applying the model of teaching listening. Thus, it was very demanded to help the students improve their listening skill through the appropriate teaching model to teach listening in order that they are easy to catch what the speakers tell about. An alternative for this condition was by applying shadowing in teaching and learning process of listening.

The general objective of this research was to know whether shadowing could improve the listening skill in the third semester students of English department of education faculty of Hasyim Asy'ari University (UNHASY) Tebuireng Jombang in the academic year of 2016/2017. Meanwhile, the specific objective was to describe the lecturer's activities, the students' activities, and the students' responses during the implementation of shadowing in the listening class.

\section{Previous Studies}

There are several previous studies that have been conducted by some researchers explaining about the success of shadowing to improve students' language skills. Firstly, Omar and Umehara (2010: 199) in their research entitled "Using a Shadowing Technique to Improve English Pronunciation Deficient Adult Japanese Learners: An Action Research on Expatriate Japanese Adult Learners" conclude that there was the improvement on the participants' English pronunciation, especially in their English rhythms. Next, Horiyama (2012: 113) in his research entitled "The Development of English Language Skills through Shadowing Exercises" states that shadowing exercises improved students' English skills and boosted their motivation and active participation in the class. Other research entitled "A Pilot Study Comparing the Effects of Shadowing and Oral Reading on Oral Reading Rate" by Osato (2014: 289) found that the effects 
of shadowing were the improvements in both productive and receptive skills such as pronunciation, listening, and reading ability. Then, the research entitled "Monitoring strategy in shadowing: self-monitoring and pair-monitoring" by Hamada (2015: 4) found that the selfmonitoring and pair-monitoring groups improved their phoneme perceptions and the lower proficiency learners' listening comprehension skills of the self-monitoring group also improved. In addition, Shiota (2012: 71) in his research entitled "The Effectiveness of Shadowing on Students' Psychology in Language Learning" states that in the second language learning, the useful technique to solve the students' attitude problems was shadowing. Meanwhile, Zakeri (2014: 21) in his research entitled "The Effect of Shadowing on EFL Learners' Oral Performance in Term of Fluency" found that there was a great significant relationship between shadowing and the learners' fluency.

\section{Listening}

Listening is the first thing to be learnt before somebody learns speaking, reading, and writing. In line with this, Sevik (2012: 328) states that listening is the basic skill that must be learnt in the language learning process. In addition, Kim and Kang (2015: 175) report that many linguists and English teachers state that listening becomes the most fundamental and the most important skill among other language skills because it is a key role to study a foreign language. Then, Sevik (2012: 330) also states that listening is the same as reading which is a receptive skill because both listening and reading focus on receiving information from an outside source. Meanwhile, Murjani (2010: 2) states that listening is an active skill because listening is not only the process of hearing what the speakers say but also the process of integrating what the speakers talk about with the information in the real world. Thus, it can be concluded that listening is the most fundamental and important skill which is not only a receptive skill but also an active skill to be learnt in the first language learning process.

Bozorgian and Pillay (2013: 105) state that listening covers a complex process. Listening is a process consisting of a conscious attention, reception, perception, and the assignment of meaning and response to the message (Kim and Kang, 2015: 42). In line with this, Sarıcoban in Sevix (2012: 330) argues that listening is the ability consisting of identifying and understanding what others are saying which involves understanding accent or pronunciation, grammar, and 
vocabulary of the speaker, and grasping its meaning. Furthermore, Marzban and Abdollahi (2013: 239) state that in the process of comprehending the spoken messages in the listening text, the listeners must integrate information from a range of sources, such as phonetics, phonological, prosodic, lexical, syntactic, semantic, and pragmatic. Then, Yonezaki (2014: 22) argues that a person commonly experiences three stages in the listening process, such as perceiving sounds (perception), decoding sounds to recognize them as certain linguistic forms (recognition), and comprehending the meaning of the forms (comprehension). In short, it can be said that listening is the process of comprehending what the speaker talks about by the listener through three stages, which are perception, recognition, and comprehension.

Then, Walker (2014: 172) states that the difficulties in learning listening cover three features, linguistic features, cultural features, and psychological features. The linguistic features consist of pronunciation, word boundaries, intonation, sentence and word stress. The cultural features consist of the students' and the language cultural background and the regional accents. Meanwhile, the psychological features consist of bottom-up and top-down processes, metacognition, metacognitive regulation, metacognitive knowledge, and metacognitive experience.

\section{Shadowing}

Shiota (2012: 78) states that shadowing is a training technique which is used to improve the interpreting skills. Shiki, et al in Zakeri (2014: 21) state that shadowing is an online repeating speech which must be done immediately. In this case, the listener immediately repeats what the speaker says without any pause. Horiyama (2012: 115) explains the steps of shadowing as follows: (1) concentrating on the correct pronunciation when shadowing the listening text, (2) attending to the meaning of the listening text, and (3) reproducing the listening text by picturing it. Next, Kadota and Tamai in Hamada (2012: 7) give several steps: (1) dictation cloze, (2) mumbling, (3) parallel reading, (4) checking the understanding of the written text, (5) shadowing three times, (6) checking with the written texts for three minutes for sounds and the meanings that the listener could not understand, (7) content shadowing by concentrating on both shadowing and interpreting the meaning of the listening text, (8) dictation cloze (the same as the step 1), and (9) checking the answers. 


\section{METHODOLOGY}

The design of this research was a collaborative classroom action research. It was a cyclical process which consisted of four main steps: planning the action, implementing the action, observing the action, and reflecting the action. The lecturer was as the researcher in this research. She collaborated with a collaborator equipped with a Semester of Teaching Learning Planning (RPS) of listening for the third semester and observation sheets containing field notes to write everything related to the lecturer's activities, students' activities, and students' responses during the implementation of shadowing in listening class. Two cycles were done in this research. Every cycle had two meetings. Then, the subjects of the research were 18 students of the third semester of English department of education faculty in the academic year of 2016/2017, Hasyim Asy'ari University (UNHASY) Tebuireng Jombang.

\section{Techniques of Collecting Data and Data Analysis}

Techniques of collecting data used in this research were observation and listening test in the post-test having been held. Observation was done by informing everything happening in the class on the field notes which were written by the collaborator in every meeting in the cycle. Meanwhile, the post-test was done in the meeting after the cycle had finished. Then, techniques of data analysis used in this research consisted of descriptive analysis and statistical analysis. The descriptive analysis consisted of the observation data which were analyzed to know the lecturer's activities, the students' activities, and the students' responses during the implementation of shadowing. Next, the statistical analysis was to know the improvement of the students' listening skill and the percentage of the students passing the minimum criteria mastery. To know the improvement of the students' listening skill, the researcher compared the mean score of pre-test, post test I, and post test II. Then, to know whether or not the improvement of the mean scores was significant, it was consulted to the computational result of SPSS t-test by using SPSS version 20. The criteria of the success of this research itself was when $75 \%$ of the students got score 75 as the minimum mastery criteria.

\section{DISCUSSION}

\section{Cycle One}


There were two meetings in cycle one. They were done in September 15 and September $22,2016$.

\section{The Lecturer's Activities}

Generally, the lecturer's activities in meeting one and in meeting two were the same. Firstly, the lecturer checked the attendance list and prepared everything needed in the listening class. Then, she explained the method of shadowing that was going to be applied in the listening class. Next, she did the shadowing steps as what she planned. Here are the steps.

a. The lecturer asked the students to shadow the sentence in the listening text as soon as they heard it and it was repeated four times

b. The lecturer had the students write down what they were saying in the shadowing

c. The lecturer got the students to find the meaning of the sentence that they have written in 5 minutes

d. The lecturer checked the answer consisting of the written sentence and the meaning found by the students together with the entire the class.

At those two meetings, the lecturer was in front of the class while playing and replaying the listening text. She did not give time limitation when the students shadowed and wrote the sentence spoken by the second person in the listening text. Then, she also did nothing when knowing that her students did not shadow the sentence which the second speaker said as soon as they heard it. She let the students shadow the sentence not as soon as they heard it even though at first she instructed the students to shadow the sentence as soon as they heard it.

\section{The Students'Activities}

In meeting one and meeting two, basically the students did what the lecturer instructed. The following are the descriptions of the students' activities.

a. The students shadowed the sentence in the listening text that they heard

b. The students wrote down what they were saying in the shadowing

c. The students found the meaning of the sentence that they have written in 5 minutes

d. The students discussed the answer consisting of the written sentence and the meaning together with the entire the class. 
At a whole activity in meeting one, all the students did not shadow the sentence in the listening text played by the lecturer directly. They shadowed the sentence in the listening text when it was replayed in the second time. When first playing, they still paid attention carefully to the listening text while writing down the text in their papers. Most of the students' writing was still influenced by the words of the choices in their worksheet. Besides, some students were laughing while shadowing the sentence. Then, the students found the meaning of the sentence that they shadowed and wrote by matching it with the choices prepared in their worksheet.

Some of the students shadowed the sentence in the listening text played by the lecturer in the first playing in meeting two. Other students still shadowed when the lecturer replayed the recording in the second turn. It was exactly the same as the activities in meeting one. They still paid attention carefully to the listening text when first playing. They did it while writing down the text in their papers. No student was laughing while shadowing the sentence in this meeting. They started to be confident to shadow the sentence of the second speaker's saying even though they did not feel sure that what they said was correct. They also tried not to be influenced by the words of the choices prepared in their worksheet even though they heard the similar sound to the words in the choices. They did not want to be trapped anymore.

The meeting after meeting two in cycle one was for post-test I. It was in September 29, 2016. The mean score of this post-test was 74.2. The students who passed the minimum mastery criteria were $61 \%$. That is why cycle one was considered unsuccessful.

\section{The Students' Responses}

In meeting one, the students were still not comfortable with shadowing model applied by the lecturer. It was because they were used to listening to the listening text by paying full attention carefully and writing down it in their papers without repeating it in the loud voices. Most of the students were still silent when the time to shadow the listening text came. They were afraid of making mistakes because they were not sure about what they heard whether it was the same as the speaker said in the recording. Besides, they complained that the speaker in the recording spoke very fast.

Meanwhile, the students seemed rather comfortable with shadowing model in meeting two. They tried to follow what the lecturer instructed in meeting two. It was proven by some of 
the students who were shadowing the sentence of the second speaker's saying in the recording in the first playing. They did it loudly while other students were busy with their papers and still paying attention to the next replaying. When the second replaying came, there were only two students who did not shadow the sentence that they heard. Both of the students looked at each other.

\section{Cycle Two}

This cycle also consisted of two meetings which were done in October 6 and October 11, 2016.

\section{The Lecturer's Activities}

As usual, the lecturer checked the attendance list and prepared everything needed in the listening class both in meeting one and meeting two. Then, she explained what the students had to do in the method of shadowing that was going to be applied. She motivated the students to shadow the sentence as soon as they could catch what the speaker said in the recording. Next, she did the shadowing steps as what she planned in cycle two. The steps are the followings.

a. The lecturer asked the students to shadow the sentence in the listening text in 2 minutes as soon as they heard it and it was repeated four times

b. The lecturer had the students write down what they were saying in the shadowing in 5 minutes after all the shadowing section finished

c. The lecturer got the students to find the meaning of the sentence that they have written in 5 minutes

d. The lecturer checked the answer consisting of the written sentence and the meaning found by the students together with the entire the class.

In meeting one of this cycle, the lecturer was not only in front of the class to play and replay the listening text but also stand in the space room between table A and table B to notice the students' shadowing. She had already given time limitation for the students to shadow and to write the sentence spoken by the second person in the listening text. Then, she motivated her students to shadow the sentence that the second speaker said as soon as they heard it. She also asked what the students' difficulties in shadowing the speaker's saying. 
In meeting two, the lecturer did what she had done in meeting one. She really paid attention to the time limitation when the students shadowed and wrote the sentence spoken by the second person in the listening text. After the time to shadow finished, she replayed the recording. It was done for four times.

\section{The Students'Activities}

In this meeting, the students did what the lecturer instructed. The following are the descriptions of the students' activities.

a. The students shadowed the sentence in the listening text that they heard in 2 minutes

b. The students wrote down what they were saying in the shadowing in 5 minutes

c. The students found the meaning of the sentence that they have written in 5 minutes

d. The students discussed the answer consisting of the written sentence and the meaning together with the entire the class.

The students' activities were little different from those in cycle one. Most of the students had already shadowed the sentence in the listening text played by the lecturer directly even though their sentence was not complete yet. When the second playing, all the students shadowed the sentence. It was done until the third and the fourth replaying. After all the shadowing activity finished, the students wrote their sentence in the paper. Then, the students found the meaning of the sentence that they shadowed and wrote by matching it with the choices prepared in their worksheet.

The students' activities in meeting one were different from those in meeting one. All of the students had already shadowed the sentence in the listening text played by the lecturer directly even though their sentence was not complete yet. They shadowed it until the fourth replaying. After all the shadowing activity finished, the students wrote their sentence in the paper. Then, the students found the meaning of the sentence that they shadowed and wrote by matching it with the choices prepared in their worksheet.

The meeting after meeting two of cycle two was for post-test II. It was done in October 18, 2016. The mean score of the listening test in post-test II was 75. The percentage of the students passing the minimum mastery criteria was $77.8 \%$. Thus, it can be said that cycle two was successful. 


\section{The Students' Responses}

In meeting one of this cycle two, the students seemed comfortable with shadowing model applied by the lecturer. Most of the students were active when the time to shadow the listening text came. They were not afraid anymore of making mistakes even though they were not sure about what they heard whether or not it was the same as the speaker said in the recording. Besides, they looked so happy after shadowing together with entire the class. They could follow others' saying when shadowing. They looked confident to tell their sentence and their finding of the meaning of the sentence they had written.

The students seemed very comfortable with shadowing model in meeting two of this cycle. They followed what the lecturer instructed. It was proven by all of the students who were shadowing the sentence of the second speaker's saying in the recording after the first playing. They did it loudly. They said the sentence and the meaning of the sentence without being asked by the lecturer. They were very happy when knowing that their answer was true.

\section{Findings}

Besides improving listening skill of the students, the researcher found that shadowing which was applied in the listening class could improve students' vocabularies and spelling. When the students listened what the speaker said then wrote it, they often found some new words that they did not know before. Nation in Alqahtani (2015: 22) states that a language use can increase the knowledge of the vocabularies. The language use of this research is in the listening. This is strengthened by Renukadevi (2014: 60) who argues that listening can help the learners to acquire pronunciation, word stress, vocabulary, and syntax based on what the speaker says. Then, the increase of the vocabularies itself was also followed by the improvement of the students' spelling. They could distinguish the spelling of words which had similar sounds. They did it by writing and understanding the context of what the speaker was talking about. The activities in shadowing really could enrich their vocabularies and spelling as well. Meanwhile, the listening itself can improve the students' speaking skill. In this case, the students imitated the speakers' sayings and practiced them in their speaking. This finding is supported by Sun (2009: 56) who states that listening can improve speaking. 


\section{CONCLUSIONS}

The followings are the conclusions based on the results of this research.

1. Shadowing could improve listening skill in the third semester students of English department of education faculty of Hasyim Asy'ari University (UNHASY) Tebuireng Jombang in the academic year of 2016/2017.

2. The lecturer's activities in cycle one was as what she planned for cycle one. She still stood in front of the class while playing and replaying the listening text. She did not give the time limitation for shadowing and writing the sentence of the second speaker's saying. She still let the students not shadow the sentence as soon as they heard it. But the lecturer's activities had good progress in cycle two. She motivated her students to shadow as soon as they could catch the sentence of the second speaker's saying. She also gave the time limitation for shadowing and writing the sentence of the second speaker's saying.

3. The students' activities got good progress from cycle one to cycle two. Mostly, they shadowed the sentence in the second replaying. But all of the students shadowed the sentence as soon as they heard it in meeting two of cycle two. Then, their mean score also got improvement, from 74.2 in cycle one and 75 in cycle two. Meanwhile, the percentages of the students who got 75 as the minimum mastery criteria were $61 \%$ in cycle one and $77.8 \%$ in cycle two.

4. The students' responses also were different between cycle one and cycle two. In cycle one, most of the students were still confused and silent when the model of shadowing was applied in their class. But all of them were active by shadowing directly as soon as they heard the sentence of the second speaker's saying. Besides, they looked very satisfied after the class.

\section{REFERENCES}

Adelmann, K. 2012. The Art of Listening in an Educational Perspectives Listening Reception in the Mother Tounge. Journal of Education Inquiry, Volume 3 No 4, December 2012; 513 534. Retrieved September 2015, from https://dspace.mah.se/bitstream/handle/2043/15340/108978_the_art_of_eduinq_vol3_no4 dec12_513-534.pdf?sequence=2.

Alqahtani, M. 2015. The Importance of Vocabulary in Language Learning and How to be Taught. International Journal of Teaching and Education, Volume 3 No 3, 2015; 21-34. 
Retrieved December 2015, from www.iises.net/international-journal-ofteaching.../publication-detail-213?

Arono. 2014. Improving Students Listening through Interactive Multimedia in Indonesia. Journal of Language Teaching and Research, Volume 5 No 1, January 2014; 63-69. Retrieved December 2015 , from http://www.academypublication.com/issues/past/jltr/vol05/01/08.pdf.

Bozorgian, H. and Pillay, H. 2013. Enhancing Foreign language Learning through Listening Strategies Delivered in L1: An Experimental Study. International Journal of Instruction, Volume 6 No 1, January 2013; 105-122. Retrieved December 2015, from http://www.eiji.net/dosyalar/iji_2013_1_7.pdf.

Ghanbari, F. and Hashemian, M. 2015. The Effects of English Songs on Young Learners' Listening Comprehension and Pronunciation. International Journal of Language Learning and Applied Linguistics World (IJLLALW), Volume 6(3), July 2014; 367-375. Retrieved January 2016, from $w w w . i j l l a l w . o r g / f i n a l v e r s i o n 6327 . p d f$.

Hamada, Y. 2015. Monitoring strategy in shadowing: self-monitoring and pair-monitoring. The Asian EFL Journal, Professional Teaching Articles, January 2015, Issue 81, pp. 4-25. Retrieved January, 2016 from asian-efl-journal.com/wpcontent/plugins/google.../load.php?d...,

Horiyama, A. 2012. The Development of English Language Skills through Shadowing Exercises. Journal of Bunkyo Gakuin University of Foreign Studies, Bunkyo Gakuin Junior College No. 12 (2012), pp 113-123. Retrieved January 2016, from www.ubunkyo.ac.jp/center/library/113-123(Atsuko\%20Horiyama).pdf.

Kim, J. and Kang, M. 2015. The Effects of Developing English Listening Ability of Middle School Students through English Pop Songs. Asia-pacific Journal of Multimedia Services Convergent with Art, Humanities, and Sociology, Vol.5, No.2 (2015), pp.175-182. Retrieved January 2016, from www.sersc.org/journals/AJMAHS/vol5_no2_2015/19.pdf.

Marzban, A. and Abdollahi, M. 2013. The Effect of Partial Dictation on the Listening Comprehension Ability of Iranian Intermediate EFL Learners. International Research Journal of Applied and Basic Sciences, Vol. 5 (2) (2013) pp.238-244. Retrieved January 2016, from www.irjabs.com/files_site/paperlist/r_1428_130914160025.pdf.

Murjani, Wahyu T. 2010. Increasing Student Listening Comprehension Using Storytelling: An Action Research at the Second Year of SMK Harapan Kartasura. Unpublished Thesis: Muhammadiyah University of Surakarta.

Omar, Hamzah Md and Umehara, M. 2012. Using a Shadowing Technique to Improve English Pronunciation Deficient Adult Japanese Learners: An Action Research on Expatriate Japanese Adult Learners. The Journal of Asia TEFL, Vol. 7, No. 2 (2010), pp. 199-230. Retrieved January 2016, from www.asiatefl.org/main/download_pdf.php?i=173\&c=1419307792.

Osato, S. 2014. A Pilot Study Comparing the Effects of Shadowing and Oral Reading on Oral Reading Rate. Journal of Kwansei Gakuin University, Humanities Review Vol.19, 
(2014), pp.289-298. Retrieved January 2016, from kgur.kwansei.ac.jp/dspace/bitstream/10236/13206/1/19-19.pdf.

Renukadevi, D. 2014. The Role of Listening in Language Acquisition; the Chalenges \& Strategies in Teaching Listening. International Journal of Education and Information Studies, Volume 4 No 1, 59 - 63. Retrieved January 2016, from http://www.ripublication.com/ijeisv1n1/ijeisv4n1_13.pdf.

Schimdt, A. 2016. Listening Journals for Extensive and Intensive Listening Practice. Eglish Teaching Forum: United States. Retrieved August 2016, from https://americanenglish.state.gov/files/ae/resource_files/etf_54_2_pg02-11.pdf.

Sevik, M. 2012. Developing Young Learners' Listening Skills through Songs. Kastamonu Education Journal, Vol.20 No. 1 (2012), pp. 327-340. Retrieved January 2016, from www.kefdergi.com/pdf/20_1/20_1_21.pdf.

Shiota, K. 2012. The Effectiveness of Shadowing on Students' Psychology in Language Learning. Journal of Accents Asia, Vol. 5(1) (2012), pp. 71-83. Retrieved January 2016, from accentsasia.org/5-1/shiota.pdf.

Sun, W. 2009. Improving Speaking by Listening Cultivating English Thinking and Expression, Probe into the Teaching of English Business Listening. Journal of English Language Teaching, Volume 2 No 2, June 2009, 56 - 59. Retrieved January 2016, from http://files.eric.ed.gov/fulltext/EJ1082376.pdf.

Walker, N. 2014. Listening: the Most Difficult to Teach. Journal of Encuentro, 23, 2014, 167 175. Retrieved January 2016, from http://www.encuentrojournal.org/textos/Walker_LISTENING\%20.pdf

Yonezaki, H. 2014. Effectiveness of Dictation in Improving English Listening Ability of Japanese High School Students. Journal of Research Reports of Nagaoka National College of Technology, Vol. 50 (2014), pp. 21-30. Retrieved January 2016, from https://www.nagaoka-ct.ac.jp/lib/kiyo50/21yonezaki.pdf.

Zakeri, E. 2014. The Effect of Shadowing on EFL Learners' Oral Performance in Term of Fluency. International Journal of English Language Teaching Vol.2, No.1(2014), pp.2126. Retrieved January 2016, from www.eajournals.org/.../The-Effect-of-Shadowing-onEFL-Learners'-Ora... 